\title{
ガス中蒸発法を応用したナノ複合粒子の作製
}

\author{
大野 武久 \\ 岐鼻工業高等専門学校専門基礎, ₹ 501-0495 岐卓県本巣郡真正町.
}

\section{Preparation of Composite Nanoparticles by Gas-Evaporation Technique and Subsequent Vapor Condensation}

\author{
Takehisa Ohno \\ Fundamental Sci., Gifu National College of Technology, Shinsei-cho Motosu-gun, Gifu 501-0495.
}

Received December 7, 1998

\section{SYNOPSIS}

$\mathrm{X}$ - $\mathrm{Y}$ composite nanoparticles, in which $\mathrm{X}$ are $\mathrm{Al}, \mathrm{Cu}, \mathrm{Ge}$ and $\mathrm{Si}$, and $\mathrm{Y}$ are $\mathrm{In}, \mathrm{Zn}$ and $\mathrm{Mg}$, were prepared by the condensation of $\mathrm{Y}$ vapor onto flying $\mathrm{X}$ nanoparticles which were produced in advance by a gas-evaporation technique. The structural and morphological observation of these nanoparticles was carried out by means of a transmission electron microscope.

It has been found that each Al-In particle is composed of an Al sphere which is replaced in part by an In crystallite, where the $\mathrm{Si}$-In particles are composed of Si spheres with In crystallites attached to the neck of neckelace-like Si particles. $\mathrm{A} \mathrm{Cu}-\mathrm{Zn}$ particle or a $\mathrm{Ge}-\mathrm{Mg}$ particle grown under the appropriate preparation connditions was also found to be composed of two phases of $\mathrm{Cu}-\mathrm{Zn}$ alloy and $\mathrm{Zn}$ or $\mathrm{Ge}$ and $\mathrm{Mg}_{2} \mathrm{Ge}$, respectively, where the latter surrounds the former in both systems. Their morphological features are discussed in relation to the growth process with reference to their phase diagrams.

KEY WORDS

composite nanoparticles, binary systems, gas-evaporation technique, crystal growth, electron microscopy

\section{1 緒 言}

ナノメータサイズをもつ超微粒子は巨視的結晶と比へて比 表面積が格段に大きいために特異な物理化学的性質を示し， この特長を生かして, 触媒, センサー, 低温焼結剂, 導電ペー スト，生体関連材料など多方面で新しい工業材料として注目 されている．ただ，超微粒子の分散性が悪くて作製後の取り 扱い上での難点があり，また，純金属あるいは合金といった 一様組成の超微粒子では，その用途に限界がある。 そこで本 研究では，この難点・限界を克服し，新規な工業材料として ますます多方面で実用化されることをめざして，ガス中蒸発 法)を応用して超微粒子表面を他の材料で積極的にコーティ ングする手法を独自に開発した. 本報告では最初にその作製 装置の概要と作製手順を説明する。

ガス中蒸発法は超微粒子作製方法の一つとして知られおり， その特長は作製された超微粒子が清浄であることと超微粒子 の粒径・粒子数密度の制御が容易なことである. 用いるガス としては多くの場合 Ar, He などの不活性ガスである。材料を
蒸発するとその蒸気が不活性ガスにより泠却されて凝縮し超 微粒子として成長し, 超微粒子からなる煙か発生する。この 煙は作製条件を適当に選ベばローソクの焔状となり，しかも， その内部, 中間, 外部の3つの領域において超微粒子の粒径, 形態などが異なる2.5ことが知られている. その場合, 粒径に 大きく影響する作製条件は不活性ガスの圧力 $\mathrm{P}$ と蒸発源温度

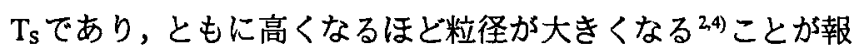
告されている.

次に，具体的な X-Y 複合粒子系として Al-In', $\mathrm{Si}^{6}-\mathrm{In}^{7}, \mathrm{Cu}-\mathrm{Zn}^{8)}$ および $\mathrm{Ge}-\mathrm{Mg}^{\mathrm{9}}$ 系のナノ複合粒子に関する成長について述べ る.このうち, Al-In系は高温において2 液相が偏晶反応を示 すか，室温で互いにまったく固溶しない。この系ではメカニ カルアロイング法によりAI粉とIn粉を機械的に混合して合金 化させた例1が報告されている.Si-In系では高温でSiがわず かに溶けたIn 融液と Si 固体とが共存するが, 室温では両者は まったく固溶しない，Cu-Zn系は $\alpha$ 相， $\beta$ 相， $\gamma$ 相， $\delta$ 相， $\varepsilon$ 相 および $\eta$ 相の間で 5 組の包晶反応を示す. 最後の $\mathrm{Ge}-\mathrm{Mg}$ 系で 
は金属間化合物 $\mathrm{Mg}_{2} \mathrm{Ge}$ と $\mathrm{Ge}$ および $\mathrm{Mg}_{2} \mathrm{Ge}$ と $\mathrm{Mg}$ との間に 2 組 の共晶反応を示す．このようなバルク物質に対する熱平衡状 態図を参考にするとともに，それそれのナノ複合粒子の作製 条件とを関連させて成長過程について検討する。

\section{2 実験方法}

2.1 ナノ複合粒子作製法

Fig.1は本研究において使用したナノ複合粒子の作製装置 ${ }^{11}$ を示す. 本装置はガス中蒸発槽 (直径 $165 \mathrm{~mm}$ ),コーティンク 用の石英管(長さ $500 \mathrm{~mm}$ ) および試料捕集部の 3 つから構成さ れている. そのうち，ガス中蒸発槽には X材料加熱蒸発用の タングステンボートが取り付けてある。.また，石英管の入口 と出口には内径 $1 \mathrm{~mm}$ ，長さ $13 \mathrm{~mm}$ のノズルが取り付けてあり， 捕集部排気用のメカニカルブースターポンプ(M.B.P.)により 差動排気されている。石英管中央部には Y 材料用の石英ボー

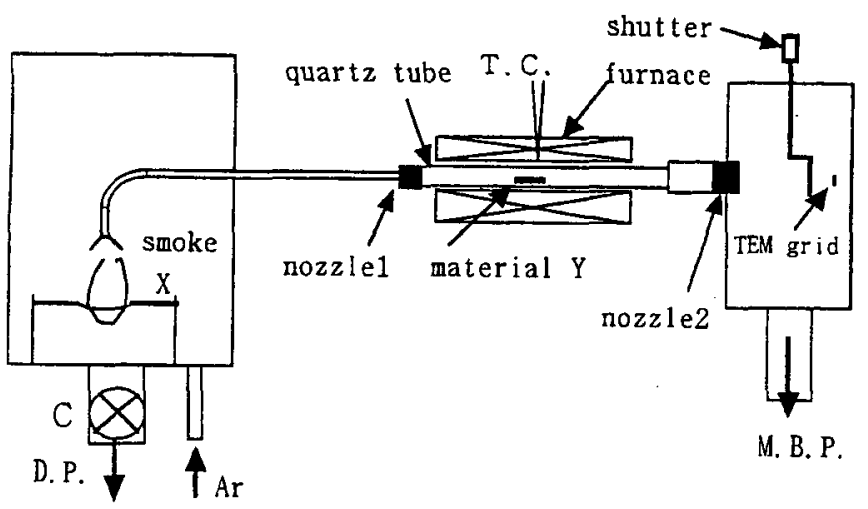

Fig.1 A schematic illustration showing experimental equipment used for the preparation of composite nanoparticles.
トがあり,そのボートの位置を中心として長さ $300 \mathrm{~mm}$ の管状 炉が石英管を覆うように設置してある。最後に，試料捕集部 には電子䫓微鏡用グリッドを隣り合わせに合計 9 枚まで取り 付けるための板があり，その前面にある回転式のシャッター を操作して任意の時刻に任意の時間だけ粒子を捕集すること が可能である。

ナノ複合粒子作製手順は次のとおりである。まずガス中蒸 発槽内を真空排気した後, 不活性ガスとして Ar 所定圧力 $\left(\mathrm{P}_{\mathrm{A}}\right)$ だけ導入する.タングステンボートを所定温度 $\left(\mathrm{T}_{\mathrm{S}}\right)$ で加 熱してX材料を蒸発させるとXナノ粒子からなる煙が発生す る.これがいわゆるガス中蒸発法である.この煙をパイブを 経由してノスル 1 から Ar ガスとともに石英管内へ噴出させ る.石英管内は管状炉加熱により所定温度 $\left(\mathrm{T}_{\mathrm{F}}\right)$ になっている. その温度に応じた密度のY蒸気が存在しているので，その中 をXナノ粒子が飛行する過程でX-Yナノ複合粒子として成長 することが期待できる．最後に，ノスル2を経て捕集部に取 り付けてある電子顕微鏡用グリッド上に粒子を直接捕集する. 2.2 試料および実験方法

ナノ複合粒子を作製する場合に，粒子の粒径および構造に 大きく影響する作製条件は上述の $\mathrm{P}_{\mathrm{Ar}}, \mathrm{T}_{\mathrm{S}}$ および $\mathrm{T}_{\mathrm{F}}$ である。本 研究において調べた 4 種類の系に対して，蒸発材料，作製条 件， $\mathrm{T}_{\mathrm{S}}$ あるいは $\mathrm{T}_{\mathrm{F}}$ における平衡蒸気圧をまとめて Table 1 に 示す．このうち $\mathrm{P}_{\mathrm{Ar}}$ はガス中蒸発槽内に導入した Ar ガス圧で ありこれはピラ二真空計を用いて測定した值を絶対圧に較 正したものである，石英管内は差動排気されていて，その内 部の $\mathrm{Ar}$ 圧力は, $\mathrm{P}_{\mathrm{Ar}}=1.3 \mathrm{kPa}$ および $\mathrm{P}_{\mathrm{Ar}}=2.7 \mathrm{kPa}$ の場合にそれぞ れおよそ0.7Pa および7Paであった. $\mathrm{T}_{\mathrm{S}}$ と $\mathrm{T}_{\mathrm{F}}$ の測定にはそれ ぞれ光高温計とPR熱電対を用いた。一度の蒸発実駼において 使用した蒝発材料は数 $10 \mathrm{mg}$ から $200 \mathrm{mg}$ ほどであった。 その

Table 1 Conditions for the preparation of composite nanoparticles.

\begin{tabular}{lccccccc}
\hline \multirow{2}{*}{ System } & \multicolumn{2}{c}{ Starting } & material & Ts & TF & PVapor & PAr \\
\cline { 2 - 4 } X-Y & Purity (\%) & Shape & $\left({ }^{\circ} \mathrm{C}\right)$ & $\left({ }^{\circ} \mathrm{C}\right)$ & $(\mathrm{Pa})$ & $(\mathrm{kPa})$ \\
\hline \multirow{2}{*}{$\mathrm{Al}-\mathrm{In}$} & $\mathrm{Al}$ & 99.999 & granule & $1150-1400$ & & $0.4-10$ & $0.27-1.3$ \\
& In & 99.99 & granule & & $560-820$ & $0.00004-0.1$ & \\
Si-In & $\mathrm{Si}$ & 99.999 & wafer & $1700-1900$ & & $3-30$ & $1.3-2.7$ \\
& In & 99.99 & granule & & $790-890$ & $0.05-0.5$ & \\
Cu-Zn & $\mathrm{Cu}$ & 99.99 & sheet & $1540-1670$ & & $70-300$ & $0.27-2.7$ \\
& $\mathrm{Zn}$ & 99.999 & wire & & $300-420$ & $0.3-10$ & \\
Ge-Mg & $\mathrm{Ge}$ & 99.999 & powder & 1650 & & 30 & $0.27-1.3$ \\
& $\mathrm{Mg}$ & 99.9 & granule & & $400-500$ & $3-8$ & \\
\hline
\end{tabular}

1) TF always contains room temperature.

2) Pvapor means equilibrium vapor pressure of each element at $T s$ or $T F$. 
うち, $\mathrm{Y}$ 材料については蒸発後の残量を測定したが,どの実 験においても半量以上が残っていた。このことから, 石英管 内には蒸発実験中に常にY 蒸気が存在していたことになる.

試料ナノ粒子の観察には透過型電子顕微鏡を用いた. 本研 究においてはナノ粒子の構造を調べることが重要であるため, 顕微鏡観察に際しては粒子の明視野像とともに電子回折図形 を撮影し,さらに特定なブラッグ反射を用いて暗視野像を撮 影した. また, 電子顕微鏡に付属した試料傾斜ステージを利 用して個々の粒子について種々の方位から観察した.

\section{3 実験結果および考察}

3.1 Al-In 系 ${ }^{11)}$ および Si-In 系

3.1.1 Al-In 系

$\mathrm{Al}$ のみを $\mathrm{P}_{\mathrm{Ar}}=0.27 \mathrm{kPa}$ 中で蒸発し, $\mathrm{T}_{\mathrm{F}}$ が室温の場合には平 均粒径 $20 \mathrm{~nm}$ の球形粒子が捕集されたが, $\mathrm{T}_{\mathrm{F}}$ が室温でないとき には粒子は捕集されなかった.この結果は次のように理解す ることができる.まず, 低圧の Ar 中で成長する粒子は小さく なる. 本研究における $\mathrm{T}_{\mathrm{F}}$ の温度範囲にバルクの $\mathrm{Al}$ の融点

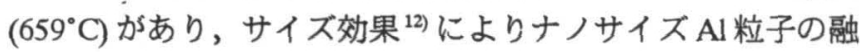
点はこれよりかなり低くなる. そのため石英管内における再 加熱により粒子は再融解・再蒸発して消失したものと考えら れる。

$\mathrm{Al}$ を蒸発しない場合, $\mathrm{T}_{\mathrm{F}}$ とは無関係に粒子は捕集されな かった.この結果は, 石英管内において In 蒸気だけからは粒 子が成長しないことを示している. ガス中蒸発法において粒 子として成長するための最低の蒸気圧は $10 \mathrm{~Pa}$ 程度である ${ }^{5)}$ されている. それに対して, 本研究の $\mathrm{T}_{\mathrm{F}}$ の温度範囲における In の平衡蒸気圧はその最低圧力以下であり, さらに, 石英管 内の $\mathrm{Ar}$ 压力 (およそ0.7〜 7Pa) も粒子生成に十分なだけ高くな かったためであると考えられる.

Fig.2 は Al と In を同時に加熱蒸発させた場合に成長した粒 子を示す. 電子顕微鏡写真 (a)に見られるすべての粒子は 2 種 類のコントラストを示している. また, その電子回折図形(b) には $\mathrm{Al}$ 相と In 相による反射が認められ, Al-Inナノ複合粒子 が成長していることがわかった. $\mathrm{Al}$ の蒸発温度 $\mathrm{T}_{\mathrm{s}}$ を高くして

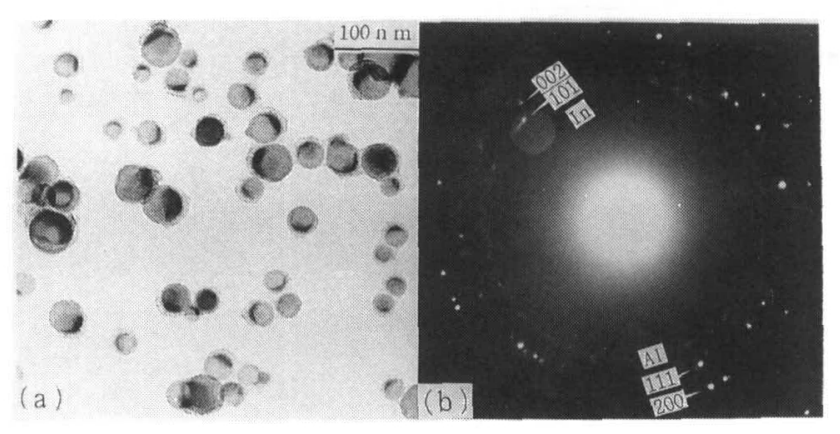

Fig.2 An electron micrograph (a) and an electron diffraction pattern (b) of $\mathrm{Al}$-In composite nanoparticles grown under the preparation conditions of $\mathrm{T}_{\mathrm{S}}=1150^{\circ} \mathrm{C}, \mathrm{T}_{\mathrm{F}}=810^{\circ} \mathrm{C}$ and $\mathrm{P}_{\mathrm{Ar}_{\mathrm{r}}}=1.3$ $\mathrm{kPa}$.
大きく成長させた粒子(Fig.3)の観察によれば, 球形の $\mathrm{Al}$ 相の 一部がIn相に置き換わった形態をしていることがわかる. 電 子顕微鏡写真に見られるコントラストの高い部分がIn相に対 応するが,これは $\mathrm{Al}$ 相に比べて In相の方が電子散乱能が高い ことによる. さらに Fig.2 と Fig.3 とを比較すると, 前者の粒 子の方が In相の割合が大きいことがわかる. 後者の粒子は $\mathrm{T}_{\mathrm{S}}$ が高い条件で成長したために粒径は大きいが, $\mathrm{T}_{\mathrm{F}}$ が前者の場 合より $40^{\circ}$ 低いために In 蒸気密度が低くて, その結果, In 相 の割合が小さくなったのである.

以上の結果から, Al-Inナノ複合粒子の成長過程をまとめ る. 第 1 段階では, ガス中蒸発法により $\mathrm{Al}$ ナノ粒子が成長す る.この際, 粒径の大小を左右するのは主に $\mathrm{P}_{\mathrm{Ar}}$ と $\mathrm{T}_{\mathrm{S}}$ である. 第2段階では, 差動排気されている石英管内に $\mathrm{Al}$ ナノ粒子が 飛行してきて, 管状炉加熱による Alナノ粒子の再融解・再蒸 発が生じ, より小さい粒子は消滅する. 第 3 段階では, 石英 管中のIn蒸気が $\mathrm{Al}$ ナ粒子表面に凝縮し, 高温時には両者は 互いに溶けあって 2 液相が共存する. 最後に, その後の泠却 過程で $\mathrm{Al}$ 相と In 相の2 相に分離する.これは,この系が室温 で互いにほとんど固溶しないためである.

3.1.2 Si-In 系

$\mathrm{T}_{\mathrm{F}}$ が $800^{\circ} \mathrm{C}$ 以下の場合に成長したナノ粒子にはIn相がほと んど認められなかった.この結果もInの平衡蒸気圧が低いこ とに起因している. Fig.4は $\mathrm{T}_{\mathrm{F}}=880^{\circ} \mathrm{C}$ において成長したナノ粒 子を示す. 電子顕微鏡写真 (a)において, 球形の 2 つの粒子の

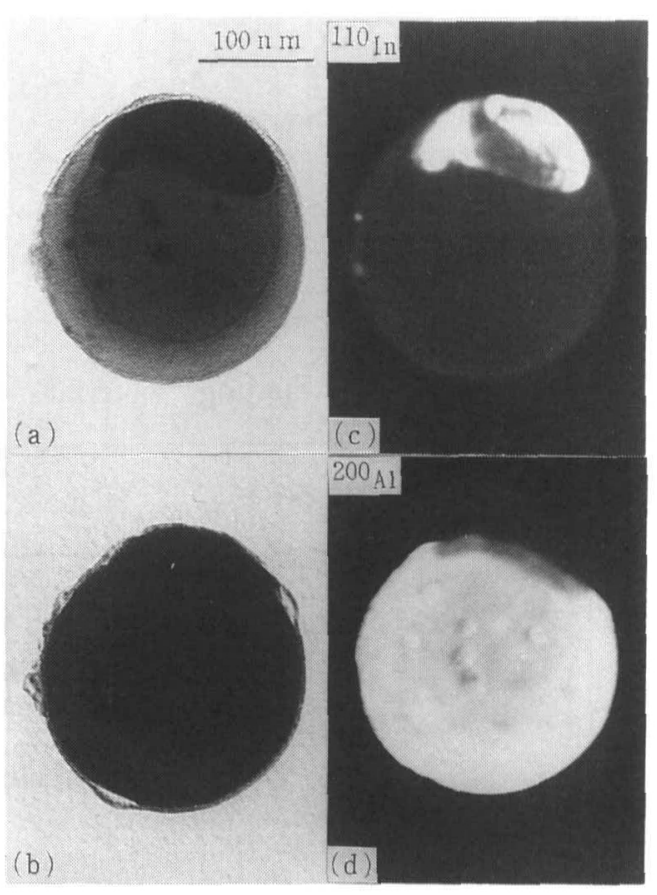

Fig.3 Electron micrographs showing an Al-In composite nanoparticle grown under the preparation conditions of $\mathrm{T}_{\mathrm{S}}=1400^{\circ} \mathrm{C}, \mathrm{T}_{\mathrm{F}}=770^{\circ} \mathrm{C}$ and $\mathrm{P}_{\mathrm{Ar}_{\mathrm{r}}}=1.3 \mathrm{kPa}$. (b) and (d) were taken for the particle tilting by $10^{\circ}$ against those of (a) and (c). (a) and (b) are bright field images, (c) and (d) dark field images taken with 110 reflection of In phase and 200 reflection of $\mathrm{Al}$ phase, respectively. 
ネック部に高いコントラストを示す物質が認められる。その 電子回折図形 (b)には Si 相と In 相の反射がある. それぞれの 反射を用いて撮影した暗視野像 (c)および (d)によれば, 球形 粒子が Si 相でネック部がIn相であることになる.この例で示 されるようにSi相とIn相とが共存する場合には, ほとんどの In相は Si相ナノ粒子のネック部などの安定した場所に存在し ていた.

ここで観察されたSi-Inナノ複合粒子の形態から, その成長 過程は次のように考えられる. 石英管内に飛行してきたSiナ ノ粒子は再加熱を受けるが, 同時にその表面には In蒸気が凝 縮してくる. Si-In系には $\mathrm{T}_{\mathrm{F}}$ の温度範囲において Siがわずかに 溶けた In 融液と Si 固体とが共存するが, 前者の溶解限度は数 at\% 以下である.つまり, Si 相と In 相とはほとんど溶解する ことがない.そのため, 凝縮してきた In 蒸気は Si ナノ粒子表 面上で最も安定した位置まで移動した後に凝固したものと考 えられる。

3.1.3 Al-Inナノ複合粒子と Si-Inナノ複合粒子の比較

$\mathrm{Al}-\mathrm{In}$ 系および Si-In 系はいずれも室温では固溶体を形成し ない. 本研究において, それらのナノ複合粒子の形態は大き く異なることが明らかになった. すなわち, 前者では $\mathrm{Al}$ 球の 一部がInで置き換わった形態であったのに対し，後者ではSi 球同士の主にネック部にIn が付着していた。この相違は十分 な In 蒸気が存在する $\mathrm{T}_{\mathrm{F}}$ の温度範囲において, 前者は互いに溶 解する 2 元系であるのに対して, 後者はほとんど溶解しない 2 元系であることを反映したものである.

$3.2 \mathrm{Cu}-\mathrm{Zn}$ 系 ${ }^{13)}$ および $\mathrm{Ge}-\mathrm{Mg}$ 系

\subsubsection{Cu- $\mathrm{Zn}$ 系}

Fig. 5 はガス中蒸発槽内に圧力 $\mathrm{P}_{\mathrm{Ar}}=2.7 \mathrm{kPa}$ の $\mathrm{Ar}$ を導入して $\mathrm{Cu}$ を蒸発しないで, $\mathrm{T}_{\mathrm{F}}=410^{\circ} \mathrm{C}$ の温度で $\mathrm{Zn}$ のみを蒸発した場 合に捕集された粒子を示す．電子顕微鏡写真 (a)には数 $10 \mathrm{~nm}$ の粒子と数 $\mathrm{nm}$ の粒子が観察される. その電子回折図形(b)は

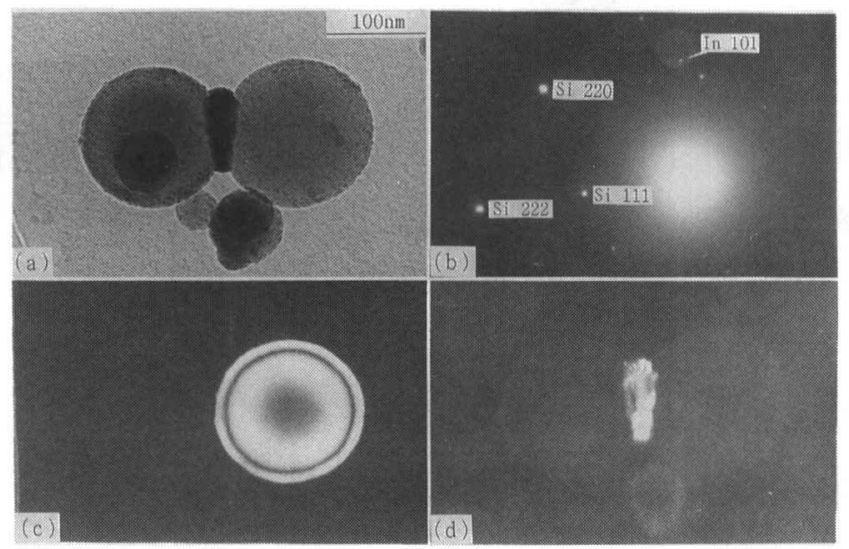

Fig.4 An electron micrograph (a) and an electron diffraction pattern (b) of $\mathrm{Si}$-In composite nanoparticles grown under the preparation conditions of $\mathrm{T}_{\mathrm{S}}=1900^{\circ} \mathrm{C}, \mathrm{T}_{\mathrm{F}}=880^{\circ} \mathrm{C}$ and $\mathrm{P}_{\mathrm{Ar}}=2.7$ $\mathrm{kPa}$. (c) and (d) are dark field images taken with 111 reflection of $\mathrm{Si}$ phase and 101 reflection of In phase, respectively.
これらが $\mathrm{Zn}$ 相であることを示している．この結果は， $\mathrm{Zn}$ の $\mathrm{T}_{\mathrm{F}}$ における平衡蒸気圧が $10 \mathrm{~Pa}$ と高くて，しかも，石英管内の アルゴンガス圧力も約 $7 \mathrm{~Pa}$ と高かったために, $\mathrm{Zn}$ 蒸気だけで ナノ粒子として成長したことによる。

Fig.6〜8は，わずかに異なった $\mathrm{P}_{\mathrm{A}}, \mathrm{T}_{\mathrm{s}}$ および $\mathrm{T}_{\mathrm{F}}$ の条件の下 で， $\mathrm{Cu}$ と $\mathrm{Zn}$ を同時に蒸発した場合に成長した粒子の典型的 な例を示す.このうち Fig.6は, より低い $\mathrm{P}_{\mathrm{Ar}}(1.3 \mathrm{kPa})$, より低 い $\mathrm{T}_{\mathrm{S}}\left(1540^{\circ} \mathrm{C}\right)$ およびより高い $\mathrm{T}_{\mathrm{F}}\left(420^{\circ} \mathrm{C}\right)$ の条件下で成長した
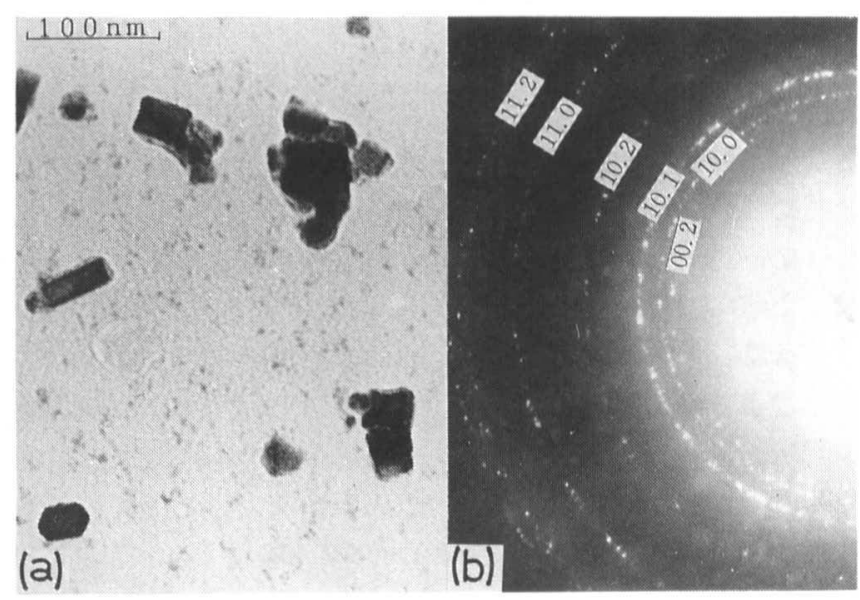

Fig.5 An electron micrograph (a) of nanoparticles grown under the preparation conditions of $\mathrm{T}_{\mathrm{S}}=1540^{\circ} \mathrm{C}, \mathrm{T}_{\mathrm{F}}=410^{\circ} \mathrm{C}$ and $\mathrm{P}_{\mathrm{A}_{\mathrm{r}}}$ $=2.7 \mathrm{kPa}$, without evaporating $\mathrm{Cu}$. An electron diffraction pattern (b) shows that they are $\mathrm{Zn}$ particles.
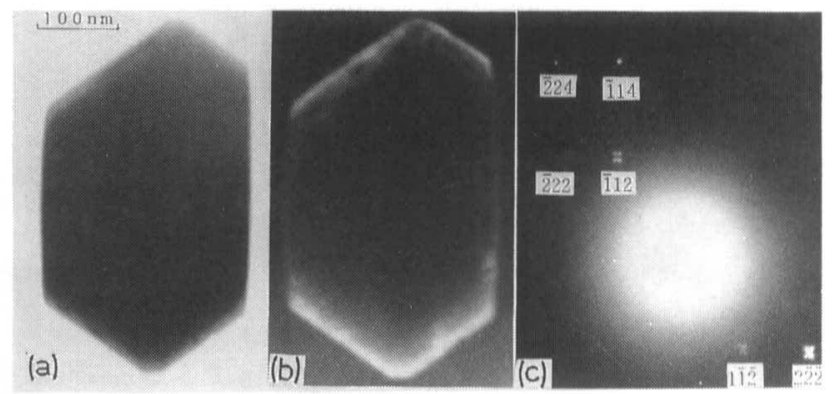

Fig.6 A Cu- $\mathrm{Zn}$ nanoparticle grown under the preparaton conditions of $\mathrm{T}_{\mathrm{S}}=1540^{\circ} \mathrm{C}, \mathrm{T}_{\mathrm{F}}=420^{\circ} \mathrm{C}$ and $\mathrm{P}_{\mathrm{Ar}}=1.3 \mathrm{kPa}$. A dark fiel image (b) was taken with $\overline{1} 14$ reflection of $\gamma$ phase of $\mathrm{Cu}-\mathrm{Zn}$ alloy.

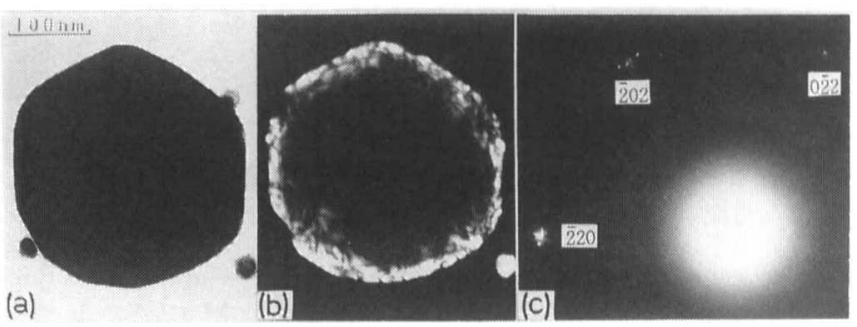

Fig.7 A Cu-Zn nanoparticle grown under the preparaton conditions of $\mathrm{T}_{\mathrm{S}}=1670^{\circ} \mathrm{C}, \mathrm{T}_{\mathrm{F}}=400^{\circ} \mathrm{C}$ and $\mathrm{P}_{\mathrm{Ar}}=2.0 \mathrm{kPa}$. A dark fiel image (b) was taken with $\overline{2} 20$ reflection of $\alpha$ phase of $\mathrm{Cu}-\mathrm{Zn}$ alloy. 
ものである.電子顕微鏡写真(a)に見られる粒子の外形は変形 した菱形 12 面体 ${ }^{14)}$ である. 電子回折図形は $\mathrm{Cu}-\mathrm{Zn}$ 系の $\gamma$-brass 相に対する [110]入射を与えていて，その中の闬反射を用い た暗視野像(b) から判断すると,この粒子全体が $\gamma$ 相であるこ とがわかる.この粒子の場合には, 高い $\mathrm{T}_{\mathrm{F}}$ のために石英管内 に十分な $\mathrm{Zn}$ 蒸気が存在し, しかも $\mathrm{Cu}$ ナノ粒子が高温に再加 熱されるため, $\mathrm{Cu}$ ナノ粒子表面に凝縮した $\mathrm{Zn}$ 蒸気はその内 部にまで入り込み, その結果, 粒子全体が一様組成の合金に なったものと考えられる.

次に, Fig.7は, より高い $\mathrm{P}_{\mathrm{Ar}}(2.0 \mathrm{kPa})$, より高い $\mathrm{T}_{\mathrm{S}}\left(1670^{\circ} \mathrm{C}\right)$ およびより低い $\mathrm{T}_{\mathrm{F}}\left(400^{\circ} \mathrm{C}\right)$ の条件下で成長したものである. Fig.5 と同様な解析をすると, この粒子は $\mathrm{Cu}-\mathrm{Zn}$ 系の $\alpha$ 相であ ることがわかった.この粒子の場合には, $\mathrm{P}_{\mathrm{A}}$ と $\mathrm{T}_{\mathrm{S}}$ がともに高 いためにCuナノ粒子の平均粒径が大きくなるが, $\mathrm{T}_{\mathrm{F}}$ が低いた めに $\mathrm{Zn}$ 蒸気密度が低く，そのために最も $\mathrm{Cu}$ に富んだ $\alpha$ 相に なったものと思われる。

最後に, Fig.8は, より高い $\mathrm{P}_{\mathrm{Ar}}(2.0 \mathrm{kPa})$, より低い $\mathrm{T}_{\mathrm{S}}\left(1540^{\circ} \mathrm{C}\right)$ およびより低い $\mathrm{T}_{\mathrm{F}}\left(400^{\circ} \mathrm{C}\right)$ の条件下で成長したものである.電 子回折図形(d) には $\gamma$-brass 相に対する [110] 入射に加えて Zn 相の反射が認められる. それぞれの反射を用いて撮影した暗 視野像(b)および(c)から判断すると,この粒子は, $\gamma$ 相の周囲
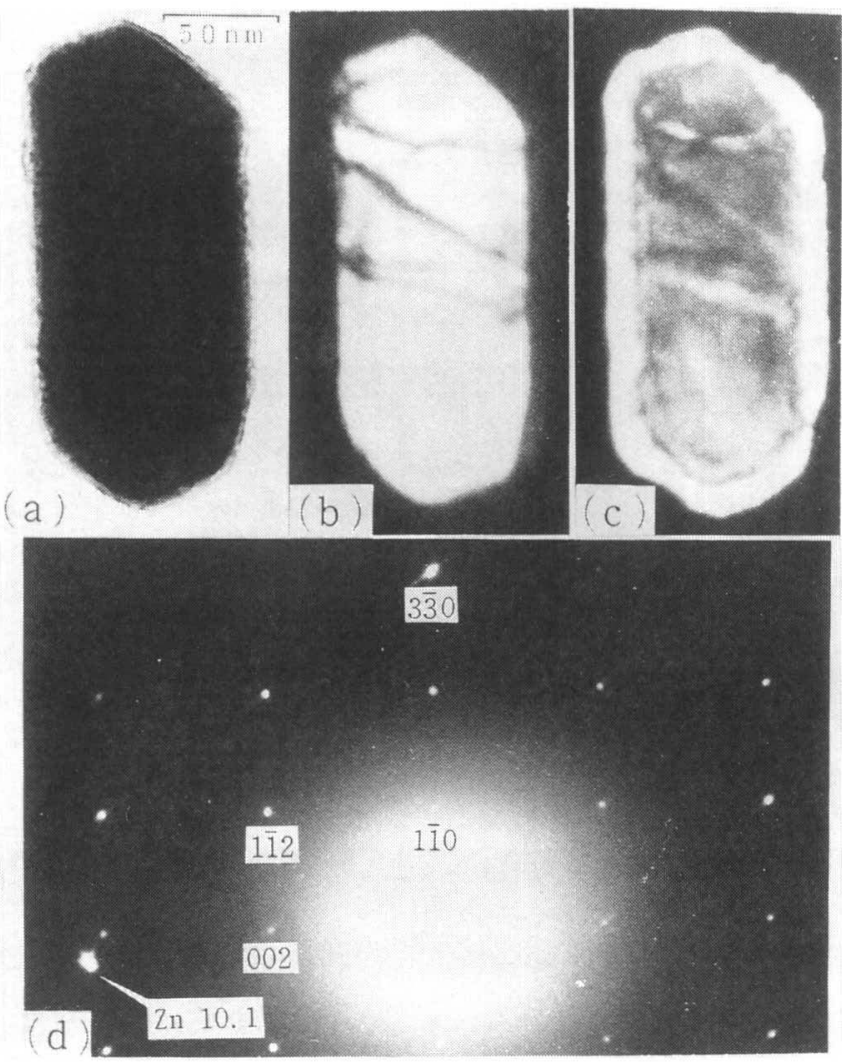

Fig.8 A Cu-Zn nanoparticle grown under the preparaton conditions of $\mathrm{T}_{\mathrm{S}}=1540^{\circ} \mathrm{C}, \mathrm{T}_{\mathrm{F}}=400^{\circ} \mathrm{C}$ and $\mathrm{P}_{\mathrm{Ar}}=2.0 \mathrm{kPa}$. An electron diffraction pattern (d) shows the [110] incidence for $\gamma$ phase of $\mathrm{Cu}-\mathrm{Zn}$ alloy, containing $\{10.1\}$ reflection of $\mathrm{Zn}$ phase. Dark field images (b) and (c) were taken with $1 \overline{1} 2$ reflection of $\gamma$ phase and $\{10.1\}$ reflection of $\mathrm{Zn}$ phase, respectively.
を $\mathrm{Zn}$ 相が取り囲んだナノ複合粒子であることがわかる.この 粒子が成長したときの作製条件は, Fig.6の場合と比べて $\mathrm{T}_{\mathrm{F}}$ が $20^{\circ} \mathrm{C}$ 低い。これら 3 つ例を比較すると, $\mathrm{Cu}-\mathrm{Zn}$ ナノ複合粒 子として成長するかどうかは, $\mathrm{P}_{\mathrm{Ar}}$ と $\mathrm{T}_{\mathrm{S}}$ の高低よりも主に $\mathrm{T}_{\mathrm{F}} に$ 関わっていると判断できる.

Fig.9はCu-Znナノ複合粒子が石英管内で成長する様子を模 式的に示す. $\mathrm{Cu}$ ナノ粒子が $\mathrm{Ar}$ ガスの流れに乗って左側から 右側に移動するにつれて, 次に示す 4 つの段階を経て成長す る.まず, $\mathrm{Cu}$ ナノ粒子が管状炉により再加熱されて融解し, 一部が再蒸発する.ここでも微粒子に対するサイズ効果 ${ }^{12)}$ か 影響しているものと考えられる. 次に, $\mathrm{Zn}$ 蒸気が $\mathrm{Cu}$ ナノ粒 子表面上に凝縮する. 続いて, 凝縮した $\mathrm{Zn}$ は融解した $\mathrm{Cu}$ ナ ノ粒子表面上で $\mathrm{Cu}$ との間で合金相を形成する. 最後に, 引き 続き合金ナノ粒子表面上へ凝縮してくる $\mathrm{Zn}$ 蒸気が凝固するこ とによりナノ複合粒子となる. 結局, 3 つの主要な作製条件 $\mathrm{P}_{\mathrm{Ar}}, \mathrm{T}_{\mathrm{S}}, \mathrm{T}_{\mathrm{F}}$ の中でも特に $\mathrm{T}_{\mathrm{F}}$ の高低のわずかな差により, ほとん どCu相のままの粒子であったり, 全体が一様な合金相の粒子 になったり, 粒子内部と表面層とで相が異なるいわゆる複合 粒子になったりする。

\subsection{2 $\mathrm{Ge}-\mathrm{Mg}$ 系}

$\mathrm{T}_{\mathrm{F}}=400^{\circ} \mathrm{C}$ において成長したナノ粒子は $\mathrm{Ge}$ だけを蒸発した 場合に成長した粒子とほぼ同様な形態 ${ }^{15)}$ を示し, その電子回 折図形にも $\mathrm{Mg}$ 相はほとんど認められなかった。一方, $\mathrm{T}_{\mathrm{F}}=500^{\circ} \mathrm{C}$ において成長したナノ粒子の電子顕微鏡写真 (Fig.10(a))には，Ge 相粒子とは大きく異なる形態を示す粒子 が観察され，その電子回折図形(b)には $\mathrm{Mg}_{2} \mathrm{Ge}$ 相の反射のみ が認められた。したがって，この場合には粒子全部が $\mathrm{Mg}_{2} \mathrm{Ge}$ 相として成長したことになる．その中でも大きな粒径をもつ 粒子の 1 例を Fig.11に示す. 電子顕微鏡写真 (a)に見られる粒 子の電子回折図形 (b) には $\mathrm{Mg}_{2} \mathrm{Ge}$ 相の 220 反射が複数個現れ た. それらを用いて撮影した暗視野像 (c) および (d) から判断 すると,この粒子は複数個の $\mathrm{Mg}_{2} \mathrm{Ge}$ 相ブロックがテトラポッ ト的に接合した形態をしていることがわかる.

Fig.12は $\mathrm{T}_{\mathrm{F}}=450^{\circ} \mathrm{C}$ において成長したナノ粒子を示す. 電子 顕微鏡写真(a)に見られる粒子の表面はひどく荒れている. 電 子回折図形 (c) には $\mathrm{Ge}$ 相の 111 反射に加えて $\mathrm{Mg}_{2} \mathrm{Ge}$ 相の 220 反射が観察される. 前者の反射を用いて撮影した暗視野像(b)

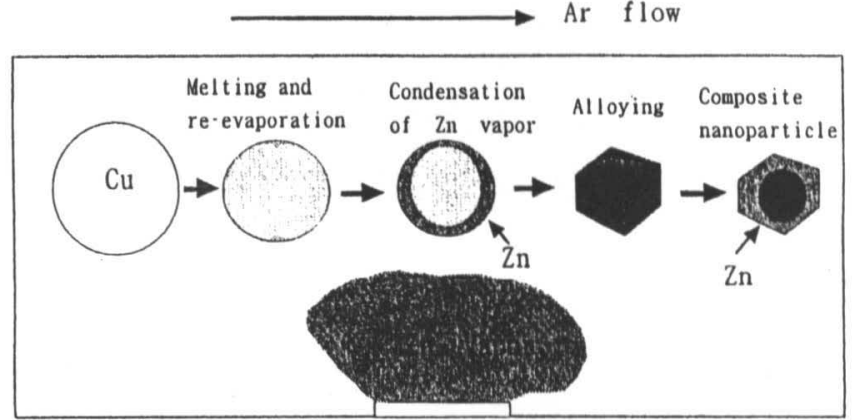

Fig.9 A schematic illustration showing the growth process of a $\mathrm{Cu}$ $\mathrm{Zn}$ composite nanoparticle. 


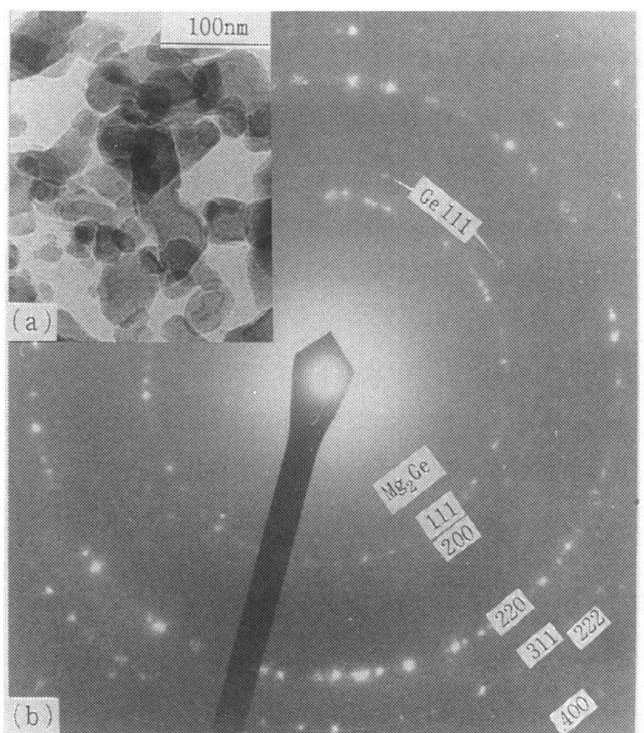

Fig.10 An electron micrograph (a) and an electron diffractin pattern (b) of $\mathrm{Ge}-\mathrm{Mg}$ nanoparticles grown under the preparaton conditions of $\mathrm{T}_{\mathrm{S}}=1650^{\circ} \mathrm{C}, \mathrm{T}_{\mathrm{F}}=500^{\circ} \mathrm{C}$ and $\mathrm{P}_{\mathrm{Ar}}=1.3 \mathrm{kPa}$. The pattern (b) shows that the particles are of $\mathrm{Mg}_{2} \mathrm{Ge}$ phase.

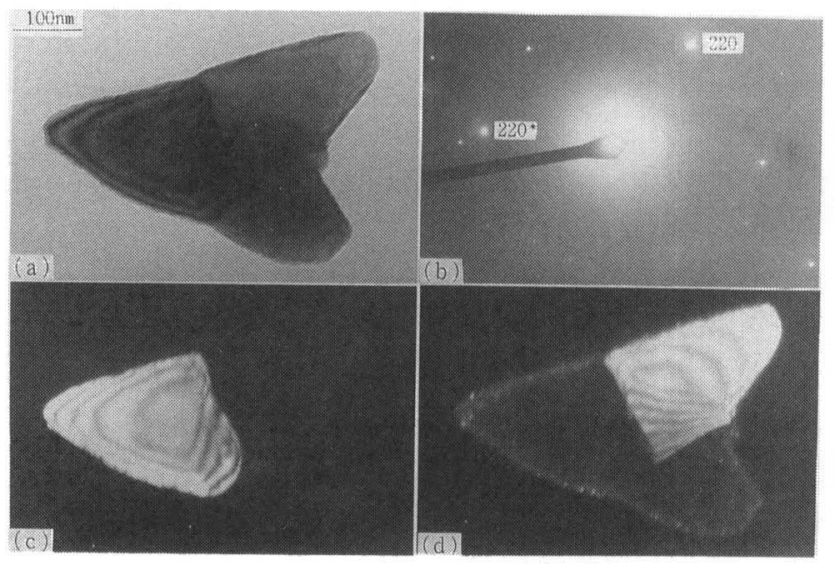

Fig.11 A Ge-Mg nanoparticle grown under the preparaton conditions of $\mathrm{T}_{\mathrm{S}}=1650^{\circ} \mathrm{C}, \mathrm{T}_{\mathrm{F}}=500^{\circ} \mathrm{C}$ and $\mathrm{P}_{\mathrm{Ar}}=1.3 \mathrm{kPa}$. The pattern (b) shows $\{220\}$ reflections of $\mathrm{Mg}_{2} \mathrm{Ge}$ phase. The dark field images (c) and (d) were taken with 220 and $220^{\circ}$ refletions shown in (b), respectively.

を見ると,粒子内部だけが複雑なコントラストを示している. 粒子表面が荒れていることを考虑すると，この粒子は内部が $\mathrm{Ge}$ 相で, 表面層が $\mathrm{Mg}_{2} \mathrm{Ge}$ 相である構造をもつ複合粒子である ことがわかる.

Fig. 13 は $\mathrm{T}_{\mathrm{F}}=440^{\circ} \mathrm{C}$ において成長したナノ粒子を示す. 電子 顕微鏡写真 (c) および (d) は (a)の粒子を $20^{\circ}$ だけ傾斜して観察 したものである. (a) および (c)の場合にそれぞれ電子回折図 形に現れた $\mathrm{Ge}$ 相の反射と $\mathrm{Mg}_{2} \mathrm{Ge}$ 相の反射を用いて撮影した 暗視野像 (b)および (d) から, この粒子の場合にも, 内部の $\mathrm{Ge}$ 相を取り巻くように角状の $\mathrm{Mg}_{2} \mathrm{Ge}$ 相が存在していることがわ かる.

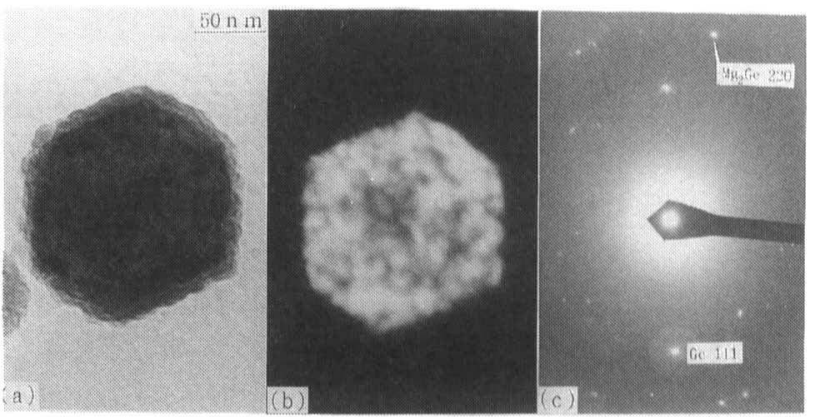

Fig.12 A Ge-Mg nanoparticle grown under the preparaton conditions of $\mathrm{T}_{\mathrm{S}}=1650^{\circ} \mathrm{C}, \mathrm{T}_{\mathrm{F}}=450^{\circ} \mathrm{C}$ and $\mathrm{P}_{\mathrm{Ar}}=1.3 \mathrm{kPa}$. The pattern (c) shows 111 reflection of $\mathrm{Ge}$ and 220 reflection of $\mathrm{Mg}_{2} \mathrm{Ge}$ phase. The dark field images (b) was taken with 111 reflection of $\mathrm{Ge}$.

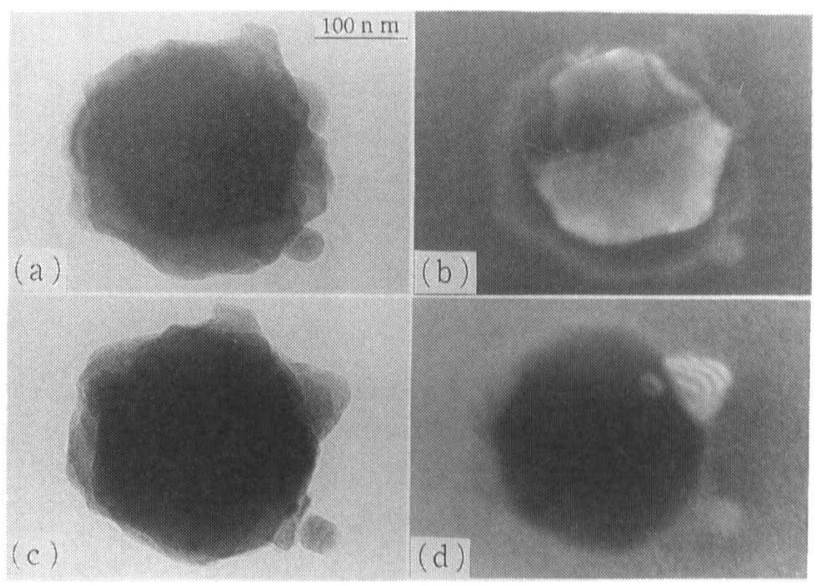

Fig.13 A Ge-Mg nanoparticle grown under the preparaton conditions of $\mathrm{T}_{\mathrm{S}}=1650^{\circ} \mathrm{C}, \mathrm{T}_{\mathrm{F}}=440^{\circ} \mathrm{C}$ and $\mathrm{P}_{\mathrm{Ar}}=1.3 \mathrm{kPa}$. (c) and (d) were taken for the particle tilting by $20^{\circ}$ against that of (a) and (b). The dark field images (b) and (d) were taken with 111 reflection of $\mathrm{Ge}$ and 111 refletion of $\mathrm{Mg}_{2} \mathrm{Ge}$ phase, respectively.

本研究で観察された Ge-Mg ナノ粒子の構造および形態は, 特に $\mathrm{T}_{\mathrm{F}}$ により大きく異なった．まず, $400^{\circ} \mathrm{C}$ 以下の場合には $\mathrm{Mg}$ はほとんど蒸発していなかった. 次に, $500^{\circ} \mathrm{C}$ の場合には 粒子全体が $\mathrm{Mg}_{2} \mathrm{Ge}$ 相であった。いわゆるナノ複合粒子は 440 $\sim 450^{\circ} \mathrm{C}$ 付近の狭い温度範囲において成長した. $\mathrm{Ge}-\mathrm{Mg}$ 系は 金属間化合物である $\mathrm{Mg}_{2} \mathrm{Ge}$ との間で $\mathrm{Ge}-\mathrm{Mg}_{2} \mathrm{Ge}, \mathrm{Mg}-\mathrm{Mg}_{2} \mathrm{Ge}$ と いう 2 組の共晶反応を示すことが知られている. そのうち本 研究において観察されたナノ複合粒子の構造は $\mathrm{Ge}-\mathrm{Mg}_{2} \mathrm{Ge}$ で あり, その場合の共晶反応温度は $680^{\circ} \mathrm{C}$ あるる.この温度は 本研究において複合粒子として成長した $\mathrm{T}_{\mathrm{F}}$ の温度範囲(440〜 $\left.450^{\circ} \mathrm{C}\right)$ より $230^{\circ} \mathrm{C}$ も高い. 理論計算 ${ }^{12}$ によれば, $\mathrm{Au}$ ナノ粒子 の場合に粒径が $10 \mathrm{~nm}$ 程度よりも小さくなると融点が急激に下 がりはじめ, 1〜2nm の粒径では 300Kにまで低下する. 本研 究においては平均粒径が数10〜200nmまでの粒子が観察され た. 正確な検討はしていないが, バルク状態の Geと比べて $\mathrm{Ge}$ ナノ粒子の融点がかなり低下しているものと考えれば, 融解 
した $\mathrm{Ge}$ ナノ粒子と $\mathrm{Mg}$ との間で $\mathrm{Mg}_{2} \mathrm{Ge}$ 相が生成した可能性が ある。

\subsubsection{Cu- $\mathrm{Zn}$ ナノ複合粒子と $\mathrm{Ge}-\mathrm{Mg}$ ナノ複合粒子の比較}

$\mathrm{Cu}-\mathrm{Zn}$ ナノ複合粒子は $\mathrm{T}_{\mathrm{F}}=400^{\circ} \mathrm{C}$ の場合に成長し, $\mathrm{Ge}-\mathrm{Mg}$ ナ ノ複合粒子は $\mathrm{T}_{\mathrm{F}}=440 \sim 450^{\circ} \mathrm{C}$ の場合に成長した. 前者では $\gamma$ brass 相の周囲を $\mathrm{Zn}$ 相が取り巻いていたのに対し，後者では $\mathrm{Ge}$ 相の周囲を $\mathrm{Mg}_{2} \mathrm{Ge}$ 相が取り巻いていた.つまり，前者では 合金相をY相か取り巻いていたのに対し，後者ではX相を金 属間化合物が取り巻いていて, 互いに逆の形態を示した。こ の相違が現れた理由を次のように考察した.まず，両者の場 合ともサイスス効果を考虑して, 管状炉加熱により Xナノ粒子 が融解していることを前提とする.その一つの実験的根损は， $\mathrm{Al}-\mathrm{In}$ 系において平均粒径 $20 \mathrm{~nm}$ 程度の $\mathrm{A} 1$ 粒子が管状炉加熱に より再蒸発して完全に消失したことである.さて，前者は包 晶反応を示す系であるために，融解しているCuナノ粒子表面 に凝縮した $\mathrm{Zn} か ゙ \mathrm{Cu}$ との間で容易に合金相となり，その後に Znがさらに凝縮して凝固したことを反映しているものと考え た. 後者は共晶反応を示す系であるために，融解している Ge ナノ粒子表面に凝縮した $\mathrm{Mg}$ か $\mathrm{Ge}$ との間で表面層から徐々に 金属間化合物を形成したことを反映しているものと考えた。

\section{4 ま と め}

ガス中蒸発法により生成したXナノ粒子が飛行している途 中において，その表面にY蒸気を凝縮させる方法によりナノ 複合粒子を作製した．得られた結果什次のとおりである。

(1) ナノ複合粒子として成長するがしないかを左右する最も大 きな条件は,ガス中蒸発法により生成されたXナノ粒子が $\mathrm{Y}$ 蒸気中を飛行する際の再加熱温度 $\mathrm{T}_{\mathrm{F}}$ である.

(2) 今回の 4 つの系のうち，Cu-Zn系をのぞけば，Y蒸気自体 が凝縮して粒子として成長することは認められなかった。

(3) Al-Inおよび Si-In 系のナノ複合粒子の形態には類似点が あったが,それは室温で互いに固溶しないことを反映して いた．前者では高温時に Al とIn とが一度溶け合った 2 液 が冷却に伴い2相分離したことを反映しており，後者では 高温時においてもSiとInがほとんど溶け合わないために， $\mathrm{Si}$ ナノ粒子表面上に凝縮した In が粒子表面上を安定な場 所まで移動して凝固したことを反映していると考えた。

(4) $\mathrm{Cu}-\mathrm{Zn}$ および Ge-Mg 系のナノ複合粒子の形態には類似点 があった．ただ，前者では $\mathrm{Zn}$ 相が Cu-Zn 合金相を取り巻 いていたのに対し，後者では $\mathrm{Mg}_{2} \mathrm{Ge}$ 相が $\mathrm{Ge}$ 相を取り巻い ていた.これらの成長過程を検討する上では, 前提として サイズ効果による融点降下を考虑し，さらに，前者では包 晶反応系であること,後者では共晶反応系であることを参 考にして，それらの形態を考察した。
謝辞

最後に，本研究を進めるにあたり協力を頂いた本学卒業生 甲斐康弘氏，佐藤裕哉氏，森裕氏，および本校在校生田中大 介氏に感謝します. 本研究は文部省科学研究費 (課題番号 08650027)および社団法人粉体粉末冶金協会の萌芽的研究助成 を受けて実施されたことを記し，謝意を表します。

\section{文献}

1) R.Uyeda: "Studies of Ultrafine Particles in Japan: Crystallography ...", Progress in Mater. Sci., 35(1991)1-96.

2) S.Yatsuya et al.: "Formation of Ultrafine Metal Particles by Gas Evapora-tion Technique. I...", Jpn. J. Appl. Phys., 12(1973) 1675-1684.

3) S.Kasukabe et al.: "Ultrafine Metal Particles formed by GasEvaporation Technique. II...", Jpn. J. Appl. Phys., 13(1974) 1714-1721.

4) T.Ohno et al.: "Formation of Ultrafine Metal Particles by GasEvaporation Technique. III...", Jpn. J. Appl. Phys., 15(1976) 1213-1217.

5) T.Hayashi et al.: "Formation of Ultrafine Metal Particles by GasEvapora-tion Technique. IV. ..", Jpn. J. Appl. Phys., 16(1977) 705-717.

6) M.Hansen: Constitution of Binary Alloys, 2nd ed., McGraw-Hill, (1958)100.

7) M.Hansen: Constitution of Binary Alloys, 2nd ed., McGraw-Hill, (1958)860.

8) M.Hansen: Constitution of Binary Alloys, 2nd ed., McGraw-Hill, (1958)649.

9) M.Hansen: Constitution of Binary Alloys, 2nd ed., McGraw-Hill, (1958) 765 .

10) K.Uenishi et al: "Microstructure of Mecanically alloyed Al-In Alloys", J. Mater. Sci., 29(1994)4860-4865.

11) T.Ohno: "Growth of Al-In Composite Nanoparticles Prepared by Gas-Evapora-tion Technique and Subsequent Vapor Condensation", Jpn. J. Appl. Phys., 34(1995)L1058-L1060.

12) N.Ichinose et al.: Superfine Particle Technology, Springer-Verlag, (1988)29.

13) 大野武久: "ガス中蒸発法による Cu-Znナノ複合粒子の作 製"，粉体および粉末治金, 44(1997)106-110.

14) T.Ohno: "Growth of Copper-Zinc and Copper-Magnesium Particles by Gas-Evaporation Technique", J. Crystal Growth, 70(1984)541-545.

15) Y.Saito et al.: "Formation of Ultrafine Particles by Gas-Evaporation Technique. V...", Jpn. J. Appl. Phys., 17(1978) 291-297. 